\title{
A $\mathbf{M}$ AKS K KEADA

\section{Tehnik Penyusunan Rencana Usaha Kecil Menengah (Ukm) Komunitas Perempuan Kepala Rumah Tangga (Pekka) Masjid Agung Palembang}

\section{Chandra Satria, Doly Nofiansyah}

Program Studi Ekonomi Syariah STEBIS IGM Palembang

Email : chandras@stebisigm.ac.id, dolynofiansyah@stebisigm.ac.id

\begin{abstract}
The community service activity entitled "Techniques for Preparing Small and Medium Enterprises (UKM) Community Heads of Households (PEKKA) of the Great Mosque of Palembang" for Entrepreneurs of the Community Head of Household (PEKKA) of the Great Mosque of Palembang Foundation was held on Sunday, November 15. 2020 through offline training facilities and a food festival activity planned for ethnic food (traditional food) in the Great Palembang mosque environment according to the time and permission of the Covid 19 group of South Sumatra Province. . The training material is in the form of strengthening the level of business production, product packaging, product marketing using digital placed markets, as well as simple financial bookkeeping which provides brief reports related to business management in monitoring the financial angle.
\end{abstract}

Keywords : Traditional food, UKM training, UKM development strategy. UKM plan

\begin{abstract}
Abstrak
Kegiatan pengabdian masyarakat yang berjudul" Tehnik Penyusunan Rencana Usaha Kecil Menengah (UKM) Komunitas Perempuan Kepala Rumah Tangga (PEKKA) Masjid Agung Palembang" untuk Pelaku usaha Komunitas Perempuan kepala Rumah Tangga (PEKKA) Yayasan Masjid Agung Palembang telah dilaksanakan pada hari Ahad tanggal 15 Nopember 2020 melalui sarana pelatihan secara luring dan direncanakan akan dilaksanakan kegiatan festival makanan etnic food (makanan tradisional) di lingkungan masjid Agung Palembang menyesuaikan dengan waktu dan izin gugus covid 19 Propinsi Sumatera Selatan. . Materi pelatihan berupan penguatan tingkat produksi usaha, pengemasan produk, pemasaran produk dengan pemanfaatan market digital placed, serta pembukuan keuanga sederhana yang memberikan laporan singkat terkait pengelolaan usaha dalam monitoring sudut keuangan.
\end{abstract}

Kata Kunci: Makanan tradisional, Pelatihan UKM, Strategi pembinaan UKM. Rencana UKM

\section{Pendahuluan}

UKM telah menjadi tulang punggung perekonomian Indonesia dan ASEAN. Sekitar 88,8-99,9\% bentuk usaha di ASEAN adalah bentuk usaha mikro, kecil dan menengah dengan penyerapan tenaga kerja mencapai 51,7-97,2\%. Bisnis ini memiliki proporsi sebesar $99,99 \%$ dari total keseluruhan pelaku usaha di Indonesia atau sebanyak 64,1 juta unit. Oleh karena itu, kerjasama untuk pengembangan dan ketahanan bisnis usaha mikro, kecil dan menengah perlu diutamakan.[1] Perkembangan UKM dalam Sembilan tahun terakhir antara 
periode 2009 - 2018 telah menunjukan peningkatan dari segi jumlah unit sejumlah awal tercatat sebesar 52,7 juta unit meningkat sampai dengan 64,1 juta di akhir tahun 2018 [2]dengan perbandingan jumlah tenaga kerja yang terlibat sebesar 96,1 juta dan juga meningkat sampai dengan angka 116,9 juta diakhir tahun 2018[3]. Berwirausaha merupakan salah satu cara untuk memperbaiki keadaan perekonomian seseorang. Usaha Mikro Kecil dan Menengah sering disingkat (UKM) saat ini dianggap sebagai cara yang efektif dalam pengentasan kemiskinan dan perekonomian bangsa. UKM bukan hal yang baru lagi di Indonesia, karena telah dikelola oleh masyarakat dan pemerintahan. Namun akhirakhir ini, kemunculan UKM mulai menurun dikarenakan cara mengelola dan memaksimalkannya kurang tertata dan masih tidak jelas. Maka tidak heran jika masih banyak sekelompok orang yang bertindak curang maupun jahat terhadap UKM atas amanahnya yang diberikan oleh masyarakat. Contoh masalahnya yaitu kurangnya perhatian dan pengawasan terhadap pemerintah, kurangnya modal yang diberikan, kurangnya fasilitas/alat-alat produksi, pendidikan dan pelatihan kepada pelaku UKM

UKM telah diatur secara hukum melalui Undang-Undang Nomor 20 Tahun 2008 tentang Usaha Mikro, Kecil dan Menengah. UKM merupakan kelompok pelaku ekonomi terbesar dalam perekonomian Indonesia dan terbukti menjadi katup pengaman perekonomian nasional dalam masa krisis, serta menjadi dinamisator pertumbuhan ekonomi pasca krisis ekonomi. Selain menjadi sektor usaha yang paling besar kontribusinya terhadap pembangunan nasional, UKM juga menciptakan peluang kerja yang cukup besar bagi tenaga kerja dalam negeri, sehingga sangat membantu upaya mengurangi pengangguran.

\section{Usaha Mikro}

Usaha Mikro sebagaimana dimaksud menurut Undang-Undang Republik Indonesia No. 20 Tahun 2008 tentang Usaha Mikro, Kecil dan Menengah yaitu usaha produktif milik orang perorangan dan/atau badan usaha perorangan yang memenuhi kriteria Usaha Mikro sebagaimana diatur dalam Undang-Undang. Adapun kriteria usaha Mikro menurut Undang-Undang Republik Indonesia No. 20 Tahun 2008 tentang Usaha Mikro, Kecil dan Menengah, antara lain:

1) Memiliki kekayaan bersih paling banyak 50 juta tidak termasuk tanah dan bangunan tempat usaha; atau

2) Memiliki hasil penjualan paling banyak 300 juta.

\section{Usaha Kecil}

Definisi usaha kecil menurut Undang-Undang Republik Indonesia No. 20 Tahun 2008 tentang Usaha Mikro, Kecil dan Menengah yaitu usaha ekonomi produktif yang berdiri sendiri yang dilakukan oleh orang perorangan yang dilakukan atau badan usaha yang bukan merupakan anak perusahaan atau bukan cabang perusahaan yang dimiliki, dikuasai, atau menjadi bagian baik langsung maupun tidak langsung dari usaha menengah atau usaha besar yang memenuhi kriteria usaha kecil sebagaimana dimaksud dalam undang-undang. Adapun kriteria usaha kecil Undang-Undang Republik Indonesia No. 20 Tahun 2008 tentang Usaha Mikro, Kecil dan Menengah, antara lain:

1) Memiliki kekayaan bersih paling banyak 50 juta sampai 500 juta, tidak termasuk tanah dan bangunan tempat usaha; atau

2) Memiliki hasil penjualan tahunan lebih dari 300 juta sampai 2.5 milyar.

\section{Usaha Menengah}


Usaha Menengah sebagaimana dimaksud dalam Undang-Undang Republik Indonesia No. 20 Tahun 2008 tentang Usaha Mikro, Kecil dan Menengah adalah usaha ekonomi produktif yang berdiri sendiri, yang dilakukan oleh orang perseorangan atau badan usaha yang bukan merupakan anak perusahaan atau cabang perusahaan yang dimiliki, dikuasai, atau menjadi bagian baik langsung maupun tidak langsung dengan usaha kecil atau usaha besar dengan jumlah kekayaan bersih atau hasil penjualan tahunan sebagaimana diatur dalam undangundang.

Adapun kriteria usaha Menengah menurut Undang-Undang Republik Indonesia No. 20 Tahun 2008 tentang Usaha Mikro, Kecil dan Menengah, antara lain:

1) Memiliki kekayaan bersih lebih dari 500 juta sampai 10 milyar, tidak termasuk tanah dan bangunan tempat usaha; atau

2) Memiliki hasil penjualan tahunan lebih dari 2.5 milyar sampai 50 milyar

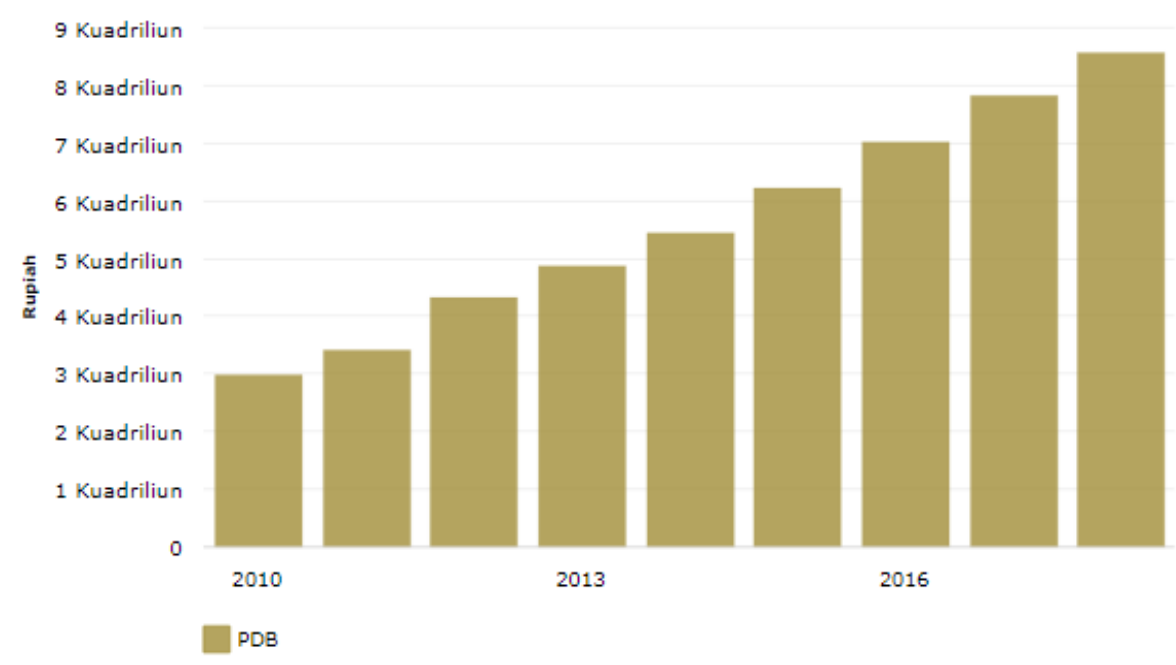

Sumber: Kementerian koperasi dan UKM Indonesia 2010-2118

Data BPS dan Kementerian Koperasi dalam Wahyudin (2013:27), dari seluruh kelas usaha menunjukkan bahwa usaha skala kecil di Indonesia menempati porsi sekitar 99\%, artinya hampir seluruh usaha di Indonesia merupakan usaha kecil, hanya $1 \%$ saja usaha menengah dan besar.

Pemerintah melalui Kementerian Koperasi dan UKM menyiapkan strategi untuk meningkatkan UKM Indonesia. Pertama, memperluas akses UKM. Hal ini penting dilakukan agar para pelaku UKM bisa menjangkau lebih banyak pelanggan, Kedua, digitalisasi. Proses hijrah ke digital ini menjadi prioritas, Ketiga, perkembangan logistik. Nyatanya, tidak hanya jaringan internet saja yang sudah mulai menjangkau banyak tempat tetapi juga internet. Penetrasi pengguna ponsel pintar juga tampaknya memengaruhi kemajuan ini. Selain itu, berbagai inovasi dari pelaku di industri turut membantu memberikan kemudahan bagi UKM. Keempat, akses pembiayaan yang ramah. Saat ini, belum banyak sistem pembiayaan yang sesuai dengan model-model yang dibutuhkan UKM. Kelima, peningkatan daya saing produk. 
kota Palembang. Kota terbesar kedua di pulau Sumatera ini setelah Kota Medan, dan menjadi bagian dari propinsi Sumatera Selatan memiliki penduduk sampai dengan akhir tahun $2018 \pm 1,6$ juta orang, dengan ketersediaan 19 pasar tradisional dan 25 pasar swasta (Direktur PD Pasar Kota Palembang) yang terdiri dari kurang lebih 12 ribu pedagang dengan jumlah 10 ribu lebih petak atau kios yang digunakan sebagai tempat berjualan. Kepala dinas koperasi dan UKM kota Palembang Ibu Ana Heryana, menyatakan bahwa sepanjang tahun 2019 ada 37000 UKM tercatat oleh Dinas Koperasi dan UKM Palembang. Target binaan sepanjang tahun 2019 sebanyak 4000 pelaku Usaha mikro kecil dan menengah kota Palembang namun, tidak lebih dari $50 \%$ yang bisa langsung dibina atau sekita 1500 UKM.[4] dan sisa target binaan sekitar 33000 UKM belum sama sekali tersentuh, angka kesenjangan ini jika dibandingkan dengan jumlah UKM yang tersedia cukup besar hanya 4 persen yang masuk binaan selama tahun 2019 . Salah satu bentuk binaan terhadap pengembangan UKM kota Palembang ini adalah dengan penyaluran dana pinjaman modal usaha tanpa agunan sebesar Rp. 3.000.000,-. Kemudahan perizinan, serta kurangnya pemanfaatan teknologi informasi dalam usaha yang dijalankan. Jumlah perusahaan skala industri kecil dan jumlah tenaga kerja yang terlibat menurut perkecamatan dikota Palembang akhir tahun 2019 adalah sebagai berikut

Yayasan Masjid Agung Palembang berlokas di km nol (O) kota palembang yang merupakan Masjid yang di tetapkan oleh pemerintah sebagai masjid nasional Indonesia. Memiliki suatu lembaga binaan organisasi yaitu komunitas pemberdayaan ibu-ibu kepala rumah tangga (PEKKA) dengan tujuan kegiatan untuk dapat memenuhi kebutuhan hidup mereka sehari-hari dengan membangun dan mengembangkan usaha dalam bentuk usaha kecil menengah. Dengan keanggotan kurang lebih 550 orang yang tersebar dalam 18 kecamatan di kota palembang, komunitas ini memiliki potensi yang besar untuk dapat memberikan peran nyata terhadap peningkatan dan kesejahteraan masyarakat khususnya kota palembang. Sebagai organisasi baru di bentuk pada tahun 2019, semangat untuk berkembang dan menunjukkan manfaat terhadap pergerakan ekonomi umat diimplementasikan dengan pembentukan unit usaha-usaha kecil yang didasari untuk memenuhi kebutuhan hidup serta mengembangkan potensi sumber daya yang dimiliki dengan keunggulan dalam bidang pengelolaan makanan etnik khas palembang. Palembang selain dikenal dengan makanan empek-empek, juga memiliki berbagai jenis makanan tradisional lainnya seperti, lenggang, burgo, bolu delapan jam, ragit, dan lain-lain. Ini semua merupakan potensi yang mulai diangkat oleh pemerintah kota palembang untuk menarik wisatawan dalam dan luar kota dengan tema wisata kuliner sambil menikmati suasana dan sejarah kota palembang sendiri sebagai bagian dari kota yang menyimpan sejarah kerajaan yang di segani di kawasan asia di zamannya. Pengembangan usaha melalui gerakan suatu komunitas telah terbukti memberikan percepatan dan keefektifan kemajuan suatu usaha agar tetap eksis dan berkembang diantara persaingan dan kompetisi yang ada. Peneliti Ratna Purwaningsih DKK menyimpulkan bahwa adanya pengaruh terhadap kinerja UKM yang berasal dari faktor internal dan eksternal. Faktor eksternal dimaksud berupa kebijakan pemerintah, kondisi sosial ekonomi dan budaya serta peranan lembaga terkait. Sedangkan pada kondisi faktor internal terdiri dari aspek sumber daya manusia, keuangan, teknis produksi, dan pemasaran.[5]. Peneliti Pradeep MD(2019) menyatakan bahwa adanya gerakan komunitas ibu-ibu akan memainkan peran penting dalam 
memastikan kesehatan yang baik dan memberdayakan perempuan di dalam rumah tangga maupun di masyarakat.[6]

Melihat uraian diatas dapat disimpulkan bahwa komunitas dibawah naungan Yayasan Masjid Agung Palembang memiliki potensi untuk memberikan dampak terhadap peningkatan kesejahteraan dan ekonomi masyarakat khususnya kota Palembang. Tapi potensi ini tentu harus disiapkan dan dikelola dengan baik agar dapat mewujudkan pelaku usaha melaksanakan kegiatan usahanya diterima di masyarakat dan berkembang sehingga menjadi usaha yang keberadaanya akan terus berlangsung dimasa-masa yang akan datang. Untuk merealisasikan potensi ini dibutuhkan suatu pembekalan dalam bentuk pelatihan kepada pelaku usaha baik dari segi pengelolaan produk, penyajian, pemasaran serta pertanggungjawaban keuangan dalam bentuk pencatatan keuangan.

\section{Metode Pengabdian}

\subsection{Tahap Persiapan}

a. Survei tempat pelaksanaan kegiatan.

b. Melaksanakan observasi dan wawancara ke pengurus Masjid Agung dan Ketua Umum PEKKA (perempuan kepala rumah tangga) untuk menentukan prioritas permasalahan yang harus segera diselesaikan.

c. Melakukan proses pengumpulan data guna mempersiapkan bahan dalam proses perancangan modul.

d. Pembuatan proposal.

e. Persiapan sarana dan sosialisasi untuk kegiatan pelatihan dan penawaran paket pelatihan.

\subsection{Tahap Pelaksanaan Kegiatan}

Pelaksanaan kegiatan pengabdian melalui pembinaan dan pelatihan ini terdiri dari beberapa kegiatan diantaranya:

a. Analisis kebutuhan: Merupakan rangkaian kegiatan yang ditujukan untuk menemukan kebutuhan yang diperlukan untuk meningkat kualitas dan rencana usaha komunitas PKKA Yayasan Masjid Agung Palembang sebagai pengguna dan pihak lain yang memiliki kepentingan.

b. Perancangan: merupakan suatu proses dalam merancang kegiatan pembinaan dan pelatihan dalam menyusun strategi usaha komunitas Organisasi PEKKA Yayasan Masjid Agung Palembang.

c. Implementasi sosialisasi Pembinaan dan pelatihan .

d. Pembinaan dan Pelatihan : melaksanakan sesuai dengan tujuan yang akan dicapai, yaitu memberikan materi pembinaan dan pelatihan tehnik penyusunan rencana usaha komunitas PEKKA Masjid Agung Palembang.

\subsection{Tahap Akhir}

Setelah pelaksanaan kegiatan pembinaan dan pelatihan ini, maka dilanjutkan dengan beberapa kegiatan berikut:

a. Melaksanakan kegiatan festival etnik food (makanan tradisional) bertempat di halaman Masjid Agung Palembang

b. Melakukan evaluasi kegiatan pelatihan menggunakan kuesioner sejauh mana pemanfaatan implementasi tindak lanjut pelatihan dan dampaknya terhadap peningkatan usaha. 
c. Evaluasi keberhasilan kegiatan ini adalah melalui questioner kepada pelaku UKM komunitas PEKKA Yayasan Masjid Agung Palembang.

d. Melihat berapa banyak keterlibatan pelaku UKM dalam mengimplemenasikan program pembinaan dan pelatihan oleh Dosen STEBIS IGM.

e. Pembuatan laporan hasil kegiatan.

d. Pengumpulan laporan hasil kegiatan

\section{Hasil dan Pembahasan}

Kegiatan pengabdian masyarakat yang berjudul" Tehnik Penyusunan Rencana Usaha Kecil Menengah (UKM) Komunitas Perempuan Kepala Rumah Tangga (PEKKA) Masjid Agung Palembang" untuk Pelaku usaha Komunitas Perempuan kepala Rumah Tangga (PEKKA) Yayasan Masjid Agung Palembang telah dilaksanakan pada hari Ahad tanggal 15 Nopember 2020 melalui sarana pelatihan secara luring dan direncanakan akan dilaksanakan kegiatan festival makanan etnic food (makanan tradisional) di lingkungan masjid Agung Palembang menyesuaikan dengan waktu dan izin gugus covid 19 Propinsi Sumatera Selatan.

Berikut beberapa Slide materi Pelatihan Penyusunan Rencana UKM Komunitas PEKKA Masjid Agung Palembang
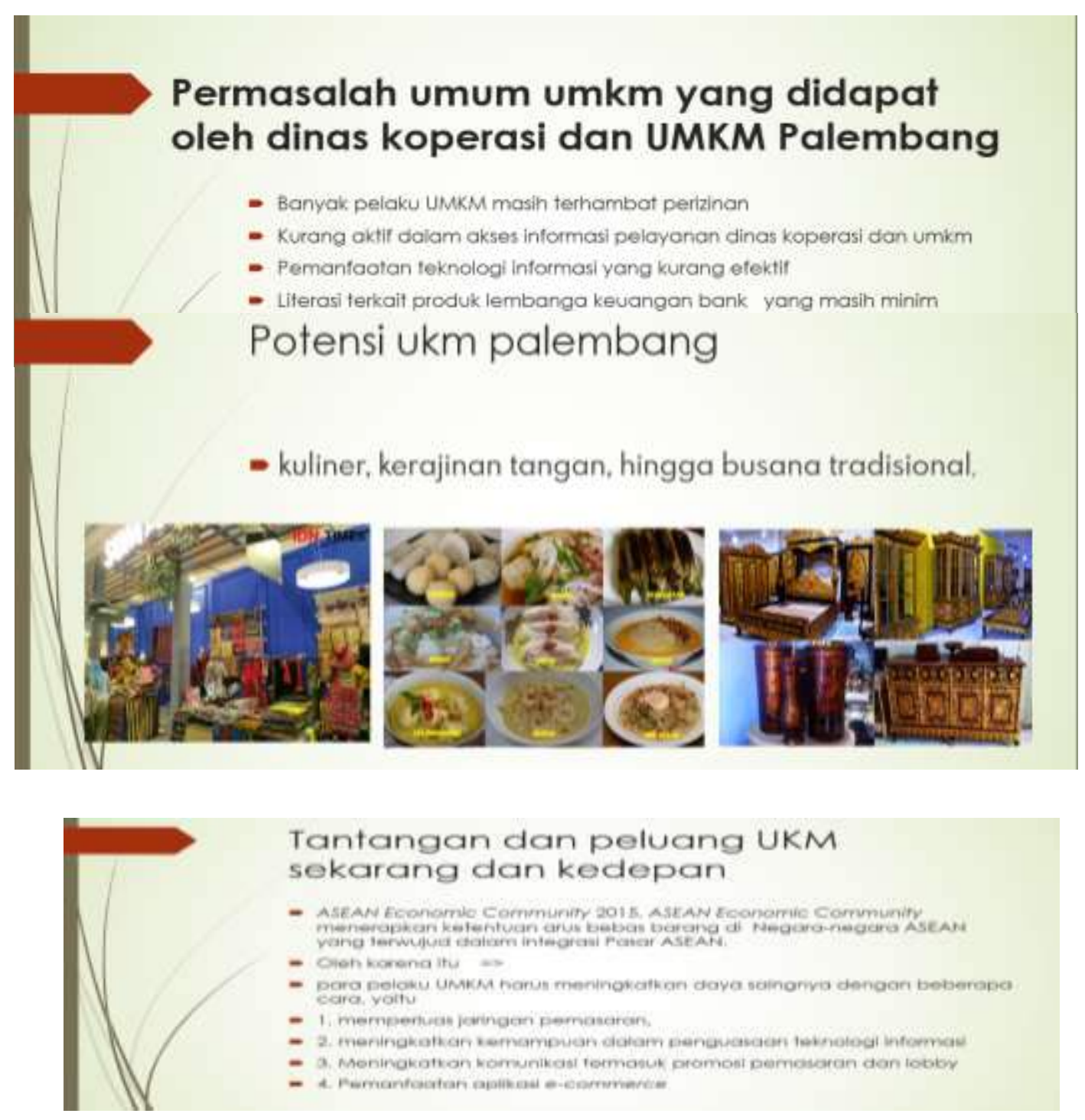


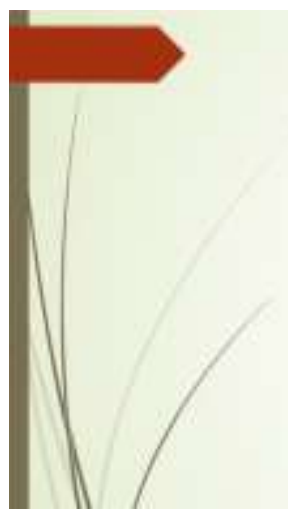

\section{Penyusunan Rencana Usaha (Business Plan)}

- Latar belakang berdiri suatu usaha Teori dasar pembukaan usaha

1. Necessify Entrepreneur yaitu Menjadi wirausaha karena ferpaksa dan desakan kebutuhan hidup.

2. Replicative Entrepreneur; yaitu yang cenderung meniru-niru bisnis yang sedang ngetren sehingga rawan terhadap persaingan dan kejatuhan.

3. Inovatip Entrepreneur yaitu, wirausaho inovatip yang terus berpikif kreatif dim melihat peluang dan meningkatkannya

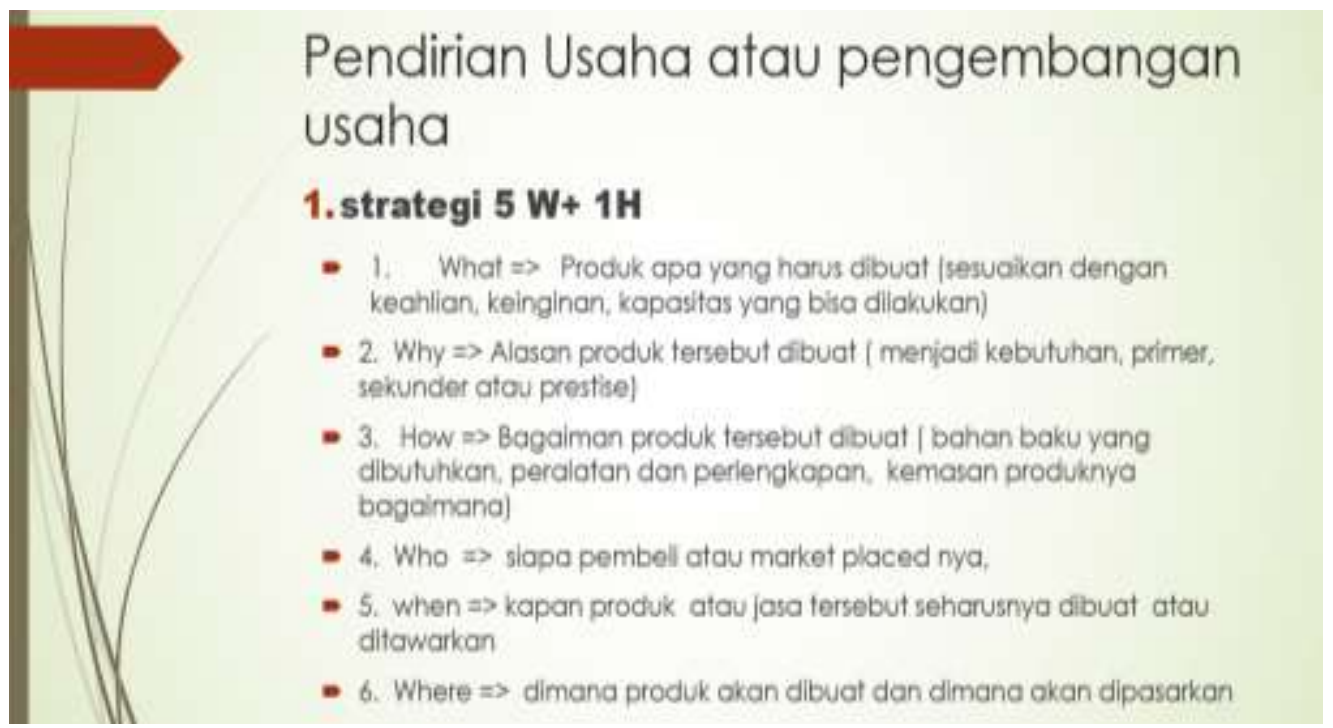


Tahap-tahap penyusunan rencana bisnis

- 1. Tahapan lde

- yaitu sesuatu yang muncul di dalam dan berkembang dalam benak pemikiran hidup manusia.

- Ide usaha yang kreatif muncul dari kseatifitas fthinking the new things! atau membuat suatu inovasi (doing the new things)

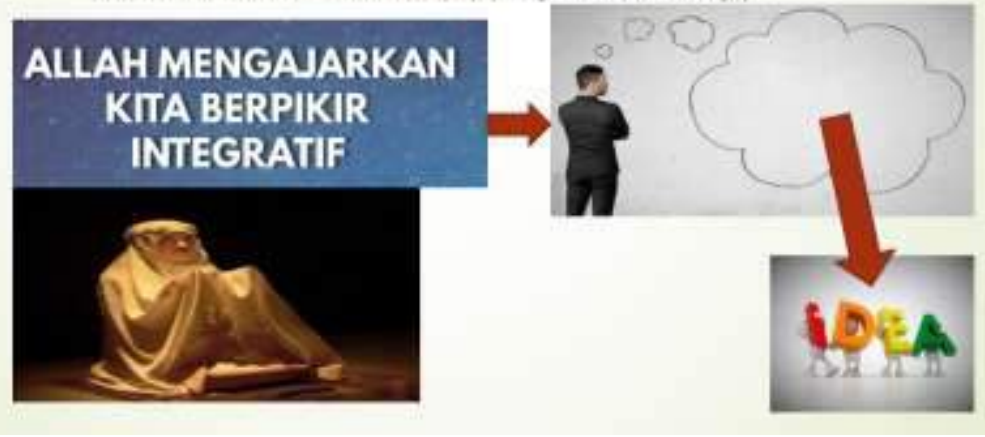

\section{Tahapan Produksi}

- 1 Pembelian atau penyediaan bahan baku...

- 2 Menjaga kualitas produksi...

- 3 Penyimpanan produk yang sudah jadi....

- 4 Melakukan pemeliharaan barang....

- 5 Proses pengiriman barang.

\section{Tahapan packaging}

- Packaging atau kemasan merupakan wadah yang digunakan untuk mengemas suatu produk yang dilengkapi dengan fullisan, label, keterangan yang menjelaskan isi, kegunaan dan informasi lain yang perlu disampaikan kepada konsumen

\section{l. Primary packaging}

yang langsung bersentuhan dengan produk dan berfungsi sebagai penjaga kualitas produk.

2. Secondary packaging yang berisi berbagai produk dari primary packaging dan berfungsi memproteksi produk.

3. Transit/Tertiary packaging yang berfungsi untuk proses transportasi pengiriman produk dan penyimpanan pada skala besar 


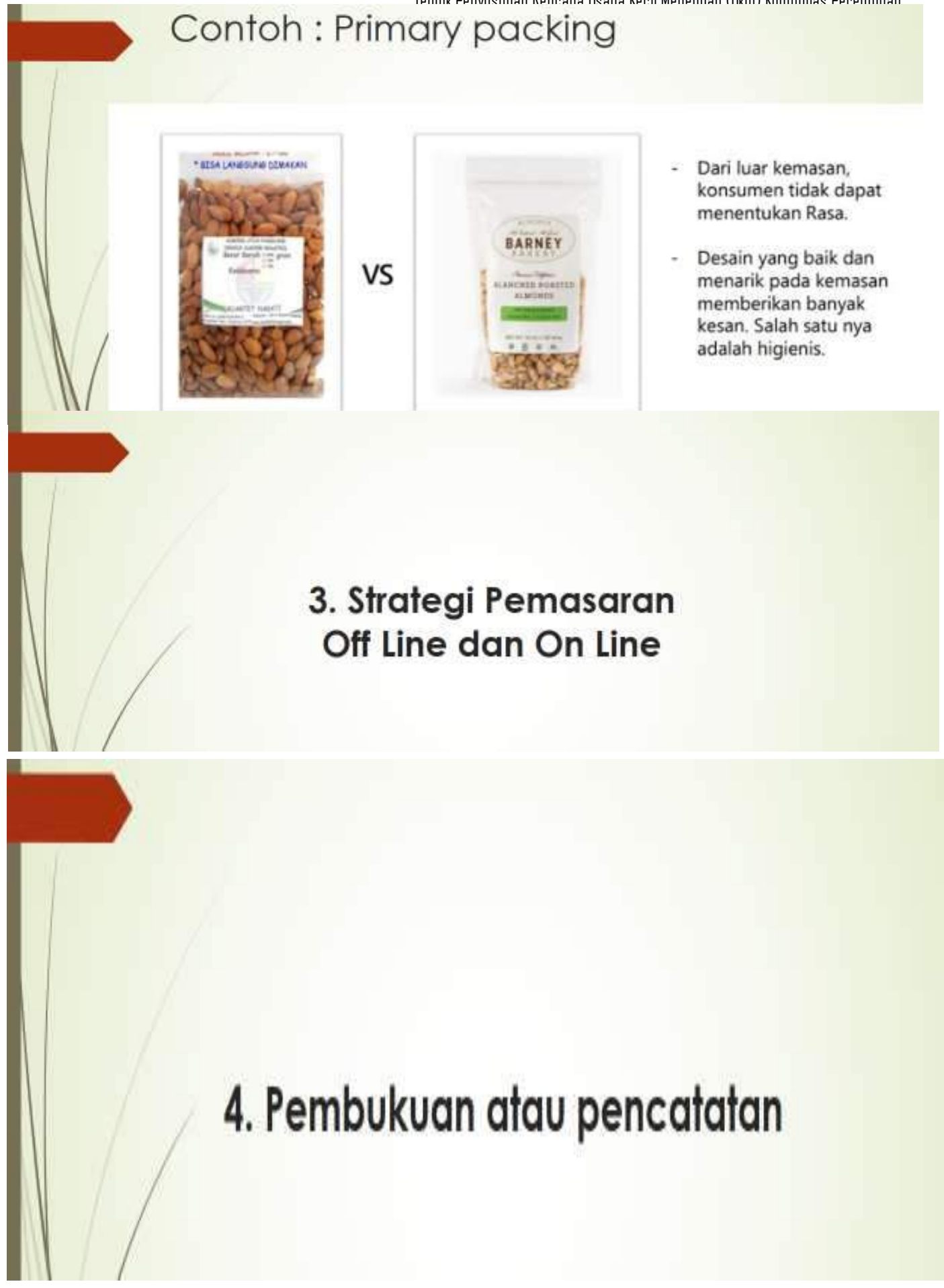




\subsection{Identifikasi Masalah di komunitas Usaha PEKKA Masjid Agung Palembang}

Kegiatan awal sebelum melaksanakan kegiatan pembinaan dan pelatihan ini diawali dengan komunikasi awal bersama pengurus PEKKA masjid Agung Palembang melakukan identifikasi masalah. Hal ini bertujuan untuk mendapatkan informasi terkait dengan permasalahan pemberdayaan unit usaha dalam organisasi PEKKA Masjid Agung Palembang. Wawancara dan diskusi yang telah dilakukan oleh tim pengabdian masyarakat terhadap Organisasi komunitas PEKKA yayasan Masjid Agung Palembang didapatkannya masalah-masalah kesulitanya Anggota PEKKA untuk dapat mengembangkan usaha dalam bidang kuliner khusunya etnik food (makanan tradisional) kota palembang, baik dalam bidang produksi, pengemasan, pemasaran serta laporan keuangan dalam bentuk pembukuan dan pelaporan keuangan sederhana.

Pelatihan dan sosialisasi rencana usaha ini dilakukan sebagai bentuk solusi awal untuk memberikan ruang informasi kepada pelaku Usaha Organisasi PEKKA agar kedepan memiliki rencana pengembangan usaha dengan kemampuang pengetahuan dibidang pengelolaan produksi usaha, pengemasan produk, pemasaran serta pelaporan keuangan sederhana atas operasional usaha dengan pengelolaan usaha tentunya diharapkan lebih baik.

\subsection{Penentuan Metode Pelatihan dan sosialisasi pemanfaatan Situs WEB Usaha STEBIS IGM}

Terdapat banyak sekali metode pelatihan dan sosialisasi yang dapat diberikan kepada peserta kegiatan pengabdian masyarakat. Metode pelatihan yang disiapan menurut teori Cherrington (1995), menjadi dua yaitu on the job traning dan off the job training. Metode pelatihan dan sosialisasi yang sesuai dalam kegiatan ini adalah metode pendekatan lecture yaitu bagian dari off the job training yaitu pelatihan dimana menyampaikan berbagai macam informasi kepada sejumlah besar orang pada waktu bersamaan. Kegiatan pelatihan dan sosialisasi dilaksanakan secara luring dengan protokol kesehatan dalam kondisi massa covid 19 yang sedang berlangsung di tahun 2020 ini. Walaupun kegiatan dilaksanakan dalam protokol kesehatan, secara prinsip tujuan dan maksud dari pelatihan ini tetap di optimalkan.

Jumlah Peserta yang hadir sebanyak 46 orang peserta terdiri dari 35 orang pelaku usaha komunitas PEKKA Yayasan Masjid Agung Palembang, 3 orang pengurus Yayasan Masjid Agung Palembang, 5 orang panitia local dan 3 orang narasumber termasuk penulis. Semua peserta dikumpulkan didalam satu ruangan rapat dengan posisi penempatan mengikuti meja bundar ditambah fasilitas penunjang sound system, infocus dan Alat tulis kantor lainnya.

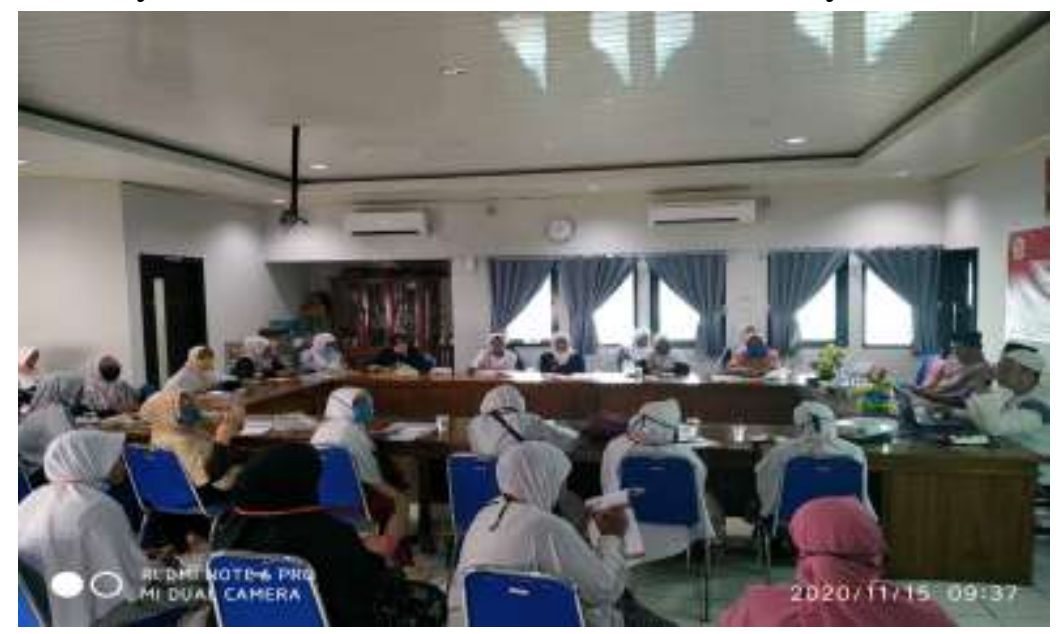




\subsection{Pelaksanaan Kegiatan Pelatihan}

Kegiatan pelatihan dan sosialisasi ini dilaksanakan pada tanggal 15 Nopember 2020 dimulai dari pagi pukul 09.00 dan selesai 12.00. Kegiatan dilaksanakan dengan sosialisasi dengan pelaku UKM Komunitas PEKKA Yayasan Masjid Agung Palembang. Lokasi pelatihan di laksanakan di ruang rapat kantor Yayasan Masjid Agung Palembang dengan protokol kesehatan, selama didalam ruang tetap menggunakan masker, menjaga jarak dan menghindari kontak fisik secara langsung.

Rundown kegiatan pelatihan dapat dilihat pada tabel 1 di bawah ini:

\begin{tabular}{|c|c|c|c|c|}
\hline No. & Tanggal & Pukul & Kegiatan & Keterangan \\
\hline 1. & 15 Nopember 2020 & 09.00 & Persiapan & $\begin{array}{lr}\text { Diikuti } & 35 \\
\text { peserta } & \text { terdiri } \\
\text { dari } & \text { Pelaku } \\
\text { usaha UKM } & \text { UKunita } \\
\text { Komuna } & \end{array}$ \\
\hline 2 & & $\begin{array}{l}09.15- \\
10.30\end{array}$ & $\begin{array}{l}\text { Pemafaran materi } \\
\text { dan sosialisasi }\end{array}$ & Narasumber \\
\hline 3 & & $\begin{array}{l}10.30- \\
10.50\end{array}$ & $\begin{array}{ll}\text { Diskusi } & \text { dan } \\
\text { pertanyaan } & \end{array}$ & Narasumber \\
\hline 4 & & $\begin{array}{l}11.20- \\
12.00\end{array}$ & $\begin{array}{l}\text { Pengisian feed back } \\
\text { questioner } \\
\text { kegiatan }\end{array}$ & Panitia \\
\hline 5 & & $\begin{array}{l}12.00- \\
12.15\end{array}$ & Selesai. & \\
\hline
\end{tabular}
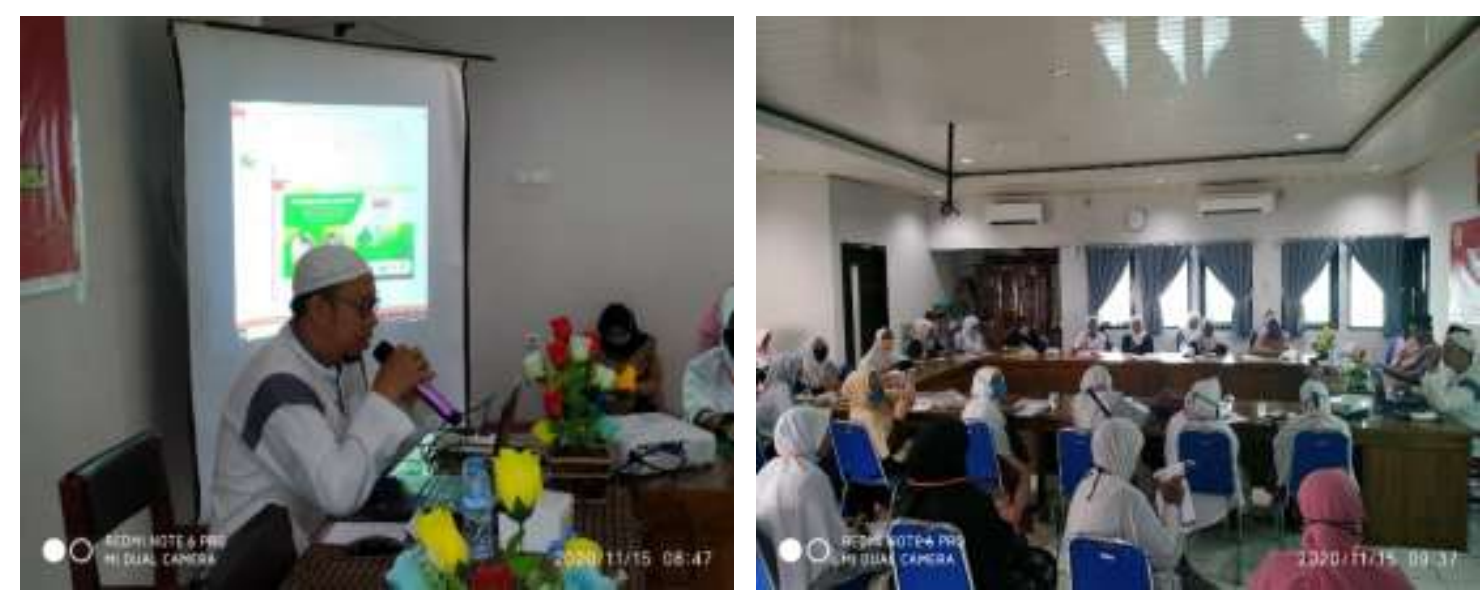

\section{Gambar diatas adalah sosialisasi dan pelatihan tehnik penyusuan rencana} UKM Komunitas PEKKA Masjid Agung Palembang.

\subsection{Evaluasi}

Kegiatan pelatihan dan sosialisasi telah dilaksanakan akan dievaluasi. Evaluasi yang digunakan adalah evaluasi tanggapan dan kesan dari peserta untuk dapat termotivasi mengimplementasikan pelatihan tehnik penyusunan rencana UKM ini sesuai dengan bidang usaha yang akan dilakukan 

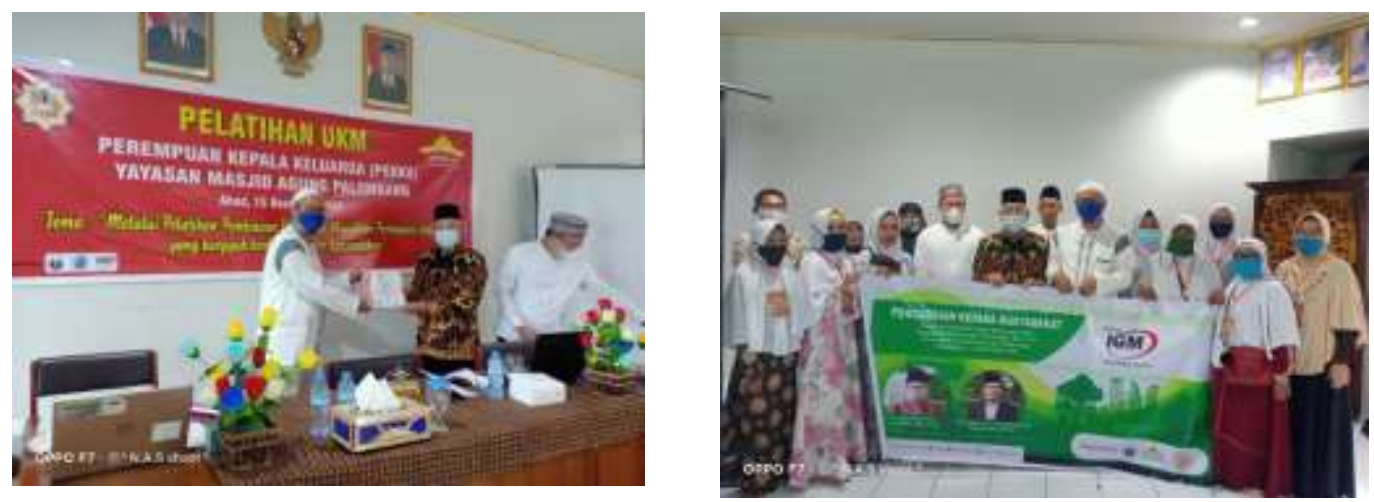

Gambar diatas menampilkan foto bersama panitia dan sebagian peserta pelatihan dan sertifikat penghargaan narasumber

\section{Simpulan}

Tahapan untuk melaksanakan kegiatan pelatihan dan sosialisasi ini diawali dengan perumusan akar masalah dan kebutuhan materi pelatihan tehnik penyusunan usaha UKM. Melihat masukan dan hasil diskusi dengan beberapa Pengurus organisasi PEKKA dan Peserta Pelaku usaha UKM PEKKA, maka ditentukan langkah untuk bisa mencari solusi dengan penyampain materi tehnik penyusunan rencan usaha UKM PEKKA, penyampaian materi disampaikan secara langsung dengan tetap menerapkan protokol kesehatan COVID 19 untuk semua orang yang terlibat didalam ruangan pelatihan. Materi pelatihan berupan penguatan tingkat produksi usaha, pengemasan produk, pemasaran produk dengan pemanfaatan market digital placed, serta pembukuan keuanga sederhana yang memberikan laporan singkat terkait pengelolaan usaha dalam monitoring sudut keuangan.

Kegiatan pelatihan ini diikiuti oleh peserta sebanyak 46 orang dari beberapa pelaku usaha UKM PEKKA Yayasan masjid Agung Palembang, Panitia dan pengurus Yayasan Masjid Agung Palembang. 


\section{Daftar Pustaka}

[1] "Pengertian, Jenis dan Perkembangan UMKM di Indonesia - Jurnal." https://www.jurnal.id/id/blog/pengertian-jenis-dan-perkembangan-umkmdi-indonesia/ (accessed Aug. 08, 2020).

[2] C. Pemerintah, "Tabel - 1 .Perkembangan data usaha Mikro,kecil,Menengah ( UMKM) dan usaha besar (UB). Tabel - 2. Perkembangan data usaha Mikro, Kecil,Menengah (UMKM) dan usaha besar (UB)," no. 1, pp. 1-2, 2015, [Online]. Available: Sumber UNdangUndang UKM.

[3] Depkop, "Perkembangan Data Usaha Mikro, Kecil, Menengah Dan Usaha Besar,"Www.Depkop.Go.Id, vol. 2000, no. 1, p. 1, 2018.

[4] "Ini Faktor Penyebab Target Binaan UMKM Kota Palembang Belum Tercapai." https://sumsel.idntimes.com/news/sumsel/feny-agustin/inifaktor-penyebab-target-binaan-umkm-kota-palembang-belum-tercapai (accessed Jul. 21, 2020).

[5] R. Purwaningsih and P. Kusuma Damar, "Analisis faktor- faktor yang mempengaruhi kinerja usaha kecil dan menengah (ukm) dengan metode structural equation modelling (studi kasus UKM berbasis industri kreatif Kota Semarang)," Pros. SNST Fak. Tek. Univ. Wahid Hasyim Semarang, vol. 6, no. 1, pp. 7-12, 2015.

[6] P. M. Devadasan and U. Srinivas, "Pemberdayaan Perempuan melalui Kelompok Swadaya-Intervensi Menuju Kesejahteraan Sosial Ekonomi Pemberdayaan Perempuan melalui Intervensi Kelompok Bantuan Mandiri Institut Studi Manajemen Srinivas Pandeshwar , Pengantar :," 2019.

[7]. Yuliana, Lia. (2012). "Peranan Perguruan Tinggi dalam Mengembangkan Sikap Mental Kewirausahaan Mahasiswa". Tersedia [online] juga di: www.uny.ac.id [diakses di Bandung, Indonesia: 23 Februari 2014].

[8]. Yusri. (2005). "Pembinaan dan Pengembangan Pendidikan Kewirausahaan pada Siswa STM (Sekolah Teknik Menengah)". Disertasi Doktor Tidak Diterbitkan. Bandung: PPs-UPI [Program Pascasarjana Universitas Pendidikan Indonesia].

[9] Darwanto. (2012). "Peran Entrepreneurship dalam Mendorong Pertumbuhan Ekonomi dan Peningkatan Kesejahteraan Masyarakat". Tersedia [online] juga di: http://eprints.undip.ac.id/36859/1/darwantoPeran_Entrepreneur_proceed_polines.pdf [diakses di Bandung, Indonesia: 20 Oktober 2014]. 
Tehnik Penyusunan Rencana Usaha Kecil Menengah (Ukm) Komunitas Perempuan

Kepala Rumah Tangga (Pekka) Masjid Agung Palembang Chandra Satria, Dolly Nopiansyah 